\title{
The Effects of Cooperative Learning on Attitude and Achievement
}

\author{
Murat GENÇ ${ }^{1, *}$ \& Fatma ŞAHİN ${ }^{2}$ \\ ${ }^{1}$ Duzce University, Duzce, TURKEY, ${ }^{2}$ Marmara University, Istanbul, \\ TURKEY
}

Received: 28.11 .2012

Accepted: 04.06.2015

\begin{abstract}
The aim of this study is to analyze the effects of cooperative learning on students' science attitude and achievement. Sampling group of the survey consists of 74 students studying in 8th grade in primary school. This study has a pretest-posttest control group research design. Science success tests and science attitude scale were used as a data collection tool. Jigsaw, academic controversy, ask and learn together, team-game-tournament, team assisted individualization which are cooperative learning's techniques were applied to the experimental group. The conventional method was applied to control group. The study was carried out 4 months. The result of this study showed that cooperative learning's techniques which were used increased students' science achievement. On the other hand, no change in terms of attitude has been seen in any group at the end of the applications lasting about four months. It's thought that it resulted from the fact that applications of this isn't enough long to influence attitude and students' attitude levels are also high enough.
\end{abstract}

Key words: Cooperative learning, attitude, achievement, primary school, science education.

DOI No:

\section{Summary}

\section{Introduction}

In cooperative learning students are assigned to small groups to complete a task, solve a problem, analyze a scenario, complete a project, or take a test. Thus, a student has success on her learning goals if and only if the rest of members of the group have success as well. Each member is responsible for the outcome of the shared goal. Groups do not become cooperative groups simply. Putting groups together in a room does not mean cooperative learning is taking place. In order to have effective cooperative learning the researchers must be careful. Cooperative learning has an atmosphere which students can find a sharing environment.

\footnotetext{
${ }^{*}$ Corresponding Author: Murat GENÇ, Faculty of Education, Duzce University, Duzce, TURKEY. 
Students who have not an anxiety of competition are tend to develop and change. Positive interdependence, face-to-face interaction, individual accountability, social skills and group processing are five essential element of cooperative learning.

Psychologists define attitudes as an expression of favor or disfavor toward a person, place, thing, or event. This can include evaluations of people, issues, objects or events. Attitude, not observable behavior is tendency to prepare behavior. Positive attitude helps to cope more easily with the daily affairs of life. Positive attitudes toward learning can increase students' success. Student attitudes on learning determine their ability and willingness to learn. Successful learners have positive beliefs and attitudes towards learning.

Science education has to be given as effective, useful and permanent from the earliest time. If students have a positive attitude of any lesson, they can be successful. The question of 'Is there any effect of cooperative learning on students' achievement and attitude towards science?" is a problem sentence of study.

\section{Methodology}

Pre-test post-test with control group follow model was used as research design, in which 37 students were in experimental group and 37 students were in the control group. In this study, by comparing the effectiveness of cooperative learning with traditional teaching methods on learning the units -"Genetic", "Reproduction and development of organisms" the level of success and attitude of the students has been investigated. The subjects were taught according to the cooperative learning approach in the experimental group while these subjects were taught according to the traditional teaching methods in the control group. Jigsaw, academic controversy, ask and learn together, team-game-tournament, team assisted individualization which are cooperative learning's techniques were applied to the experimental group.

\section{Results and Conclusion}

As a result of this study it was found that before the study there was not any different on achievement between experimental group and control group. After the application of "Genetic" unit it was seen that throughout the application process, there has been important difference in achievement in favour of the experimental group. Similarity, before "Reproduction and development of organisms" unit, there was not any different on achievement between experimental group and control group. After the application of "Reproduction and development of organisms" unit it was seen that throughout the 
application process, there has been important difference in achievement in favour of the experimental group.

As a result of this study it was found that students who have been taught with the cooperative learning were more successful than the ones have been taught with the traditional teaching approach.

On the other hand, no change in terms of attitude has been seen in any group at the end of the applications lasting about four months. It's thought that it resulted from the fact that applications of this isn't enough long to influence attitude and students' attitude levels are also high enough.

\section{Discussion and Recommendations}

Students have been thought by traditional teaching during their education and haven't shown their differences. How difficult it is to leave the individual habits students get used to different teaching method is just as difficult. This condition requires a long process.

Science achievements in both groups have same level as before application. After application change was observed. There was significant different between control group and experimental group with regard to science achievement.

Attitude of students toward science courses in both groups have same level as before application. After application no change was observed. There wasn't significant different between control group and experimental group with regard to science achievement. If longer study can be made development can be seen.

After the obtained research data we can make some recommendations.

The results of this study clearly point out that difficult topics have been taught to student by cooperative learning.

To solve social problems such studies at the school should be given to the students. The students must trust themselves for the solution of social problems. Cooperative learning environment should be created for the student. This created an atmosphere in the school should do to families. Families should support their children and prepare them to the cooperative. Students who success their lesson are more successful in daily life and business environment. To enhance their capability cooperative environments, not competitive environment, should be created. This method should be used in many environments; cooperative learning should be use more in the lesson. Such studies should be done in classes other than science lesson. Different methods should be applied to the education process. A 
method which can be used successfully can reduce the effect for a long time. Diversity will bring success with it.

In order to gain positive attitude towards science course, activities should be prepared according to the method of cooperative learning in the lessons. 


\title{
İşbirlikli Öğrenmenin Başarıya ve Tutuma Etkisi Murat GENÇ ${ }^{1,+}$, Fatma ŞAHİN ${ }^{2}$
}

\author{
${ }^{1}$ Düzce Üniversitesi, Düzce, TÜRKİYE, ${ }^{2}$ Marmara Üniversitesi, İstanbul, \\ TÜRKIYYE
}

Makale Gönderme Tarihi: 28.11.2012

Makale Kabul Tarihi: 04.06.2015

Özet -Bu araştırmada, işbirlikli öğrenme yönteminin öğrencilerin fen ve teknoloji dersine yönelik tutumlarına ve akademik başarılarına etkisi incelenmiştir. Araştırmanın çalışma grubunu, Edirne ili Anafartalar İlköğretim Okulu'ndaki 74 8. sınıf öğrencisi oluşturmaktadır. Kontrol ve deney grubu olarak seçilen öğrencilere araştırmacılar tarafından hazırlanan etkinlikler yaptırılmış ve anketler uygulanmıştır. "Genetik" ve "Canlılarda Üreme ve Gelişme" ünitelerindeki dersler; kontrol grubunda geleneksel yöntemle, deney grubunda ise işbirlikli öğrenme yönteminin Birleştirme, Akademik Çelişki, Birlikte Soralım Birlikte Öğrenelim, Takım-Oyun-Turnuva ve Takım Destekli Bireyselleştirme teknikleri ile işlenmiştir. Uygulamaların öncesi ve sonrasında her iki gruba da Fen Bilgisi Başarı Testi ve Fen Bilgisi Tutum Ölçeği uygulanmıştır. Elde edilen verilere göre deney grubunda başarı, kontrol grubuna göre .05 manidarlık düzeyinde anlamlı miktarda artmıştır. 4 ay süren uygulamalar sonunda her iki grupta da Fen ve Teknoloji dersine yönelik tutum puanlarında anlamlı değişim gözlenmemiştir. Anahtar kelimeler: İşbirlikli öğrenme, tutum, başarı, ilköğretim, fen eğitimi.

\section{Giriş}

Bireylerin olduğu gibi öğrencilerin de öğrenme stilleri, düşünme tarzları, derse yönelik tutumları ve ilgileri birbirinden farklılık göstermektedir. Bu yüzden yeni yaklaşımlar, öğretmene, öğrenmeyi en iyi şekilde gerçekleştirecek öğretim yöntemini belirleme ve uygulama yükümlülüğü vermektedir. Öğrencilerin aktif olarak derse katılımının sağlandığ1 uygulamalarla derslerdeki akademik başarıları artmaktadır. Öğrencilerin derslere aktif olarak katılımını sağlayan ve onların başarılarını artıran yöntemlerden birisi de işbirliğine dayalı öğrenmedir (Sezer \& Tokcan, 2003).

İşbirlikli öğrenme yöntemi öğrencilerin birlikte paylaşım ortamı bulabileceği bir durumdur. Arkadaşlarıyla uyum içinde çalışan öğrenciler, gelişmeye ve değişmeye açık olabileceğinden, bu yöntemle öğrencilerin başarılarının artacağı düşünülmektedir. Bilgiyi doğrudan alan değil, bilgiye nasıl ulaşacağını bilen bireyler yetiştirmek eğitim sisteminin asıl

\footnotetext{
† Sorumlu Yazar: Murat GENÇ, Eğitim Fakültesi, Düzce Üniversitesi, Düzce, TÜRKIYE.

E-mail: muratgenc@duzce.edu.tr
}

Necatibey Eğitim Fakültesi Elektronik Fen ve Matematik Eğitimi Dergisi

Necatibey Faculty of Education, Electronic Journal of Science and Mathematics Education 
amacıdır. İşbirlikli öğrenmenin geleneksel yönteme göre fen eğitiminde daha etkili olduğunu belirten çalışmalar bulunmaktadır (Okebukola, 1986; Conwell, 1988; Jones ve Steinbrink, 1991; Kaptan ve Korkmaz, 2001; Doymuş ve diğerleri, 2004).

Öğretim hizmetinin niteliğini arttırmak ve öğrencinin aktif katılımını sağlamak üzere geliştirilen işbirlikli öğrenme dünya üzerinde oldukça fazla araştırma yapılan, ülkemizde ise son yıllarda çalışılmaya başlanan bir yöntemdir. Gerek araştırmalarda, gerekse derslerde kullanım açısından giderek önem kazanan öğretim yöntemlerinden biridir (Baykara, 2000).

Sharon ve Hooper'in ifade ettiği gibi işbirlikli öğrenme öğrencilerin derse yönelik tutumlarını olumlu yönde etkilemekte ve öğrencinin kendilerini daha değerli hissetmesini sağlamaktadır (Nakiboğlu, 2001).

Millis, (1996) işbirlikli öğrenmenin; öğrenenler arasında paylaşım yapabilecekleri bir zemin oluşturduğunu, öğrenciyi öğrenmeye motive ettiğini, öğrencinin kendi öğrenmesini gerçekleştirdiğini, geri bildirim sağladığını, sınıf dışında da başarılı olabilmeleri için gerekli olan sosyal ve grup becerileri kazandırdığını ifade etmiştir.

Fen ve teknoloji dersleri özellikle çocukların doğayı ve çevresini yeni yeni tanımaya başladığı ilköğrenim döneminde çok dikkatli ve iyi öğretilmelidir. Bu nedenle dersi en verimli kılabilecek yöntem ve tekniklerin seçimi de öğretmenin alan bilgisine bağlıdır. Bu yöntem ve tekniklerden birisi de işbirlikli öğrenme yöntemidir (Kurt, 2001). Ancak işbirlikli öğrenme yönteminin grup çalışmalarıyla karıştırılmaması gerekmektedir. İşbirlikli öğrenme yönteminde küçük gruplardan farklı olarak; öğrenciler birbirlerine destek olurlar, her üye önceden belirlenmiş ve görevleri net bir role sahiptirler. Birlikte çalışma süreci önemlidir ve grup üyeleri birbirlerinin çalışmalarını incelerr ve tartışırlar (Lev, 1997).

İşbirlikli öğrenme, öğrencileri gruplara ayırıp birlikte çalışmalarını söylemekle gerçekleşmez. Öğrencilere grup ödevi yaptırmak da işbirlikli öğrenme olarak tanımlanamaz. Yalnızca öğrencilerin birbirleriyle tartışması, birbirine yardımcı olması da yeterli değildir. İşbirlikli öğrenme yönteminin hedeflere ulaşabilmesi için grupların yapılandırılmış olması gerekir. Açıkgöz tarafından (2002), ülkemizde gerçekleştirilen bir araştırmada yapılandırılmış işbirliği gruplarının daha başarılı olmasına karşın; yapılandırılmamış işbirliği gruplarının bireysel çalışma durumunun bile gerisinde kaldığı deneysel olarak belirlenmiştir.

İşbirlikli öğrenmeyi derslerde kullanmanın hem uygulayıcı hem de uygulayan açısından olumlu yönleri vardır. Grup ortamında, birlikte çalışmanın getirdiği sosyal iletişim bilginin oluşturulması açısından uygun bir ortam sağlar. Öğrenciler, araştırmak, deneyerek sonuca ulaşmak, düşüncelerini paylaşmak ve birbirlerinin öğrenmelerine yardımcı olma imkanına 
sahip olurlar. İşbirlikli öğrenme ortamında üstlenilen çeşitli görevler; öğrencilere birlikte çalışma, birbirini dinleme, tartışma ve konu üzerinde ortak karara varma gibi sosyal becerilerini geliştirmelerine imkan verir. $\mathrm{Bu}$ yöntem öğretmen için de faydalıdır. Çünkü öğrenci kendi öğrenmesinde sorumluluğu olmaktadır. Öğretmen düzenleyicidir (Korkmaz, 2002).

İşbirlikli öğrenme öğrencinin bilişsel ve duyuşsal öğrenmelerine diğer yöntemler gibi olumlu etkileri vardır. Öğrencinin akademik başarısını, özellikle çok zorlanılan konularda başta olmak üzere, arttırmakla kalmamakta öğrencinin derse yönelik tutumunu, motivasyonun ve kendisine olan güvenini de artırmaktadır.

İşbirlikli öğrenme, eğer gerektiği gibi uygulanabilirse son derece olumlu etkileri olan öğretim yöntemlerinden biridir. Amaca uygun yöntem ve teknik seçilmesi beklenen etkiye ulaşmaya yardımcı olmaktadır. Son derece karmaşık bir konunun sunumu için çeşitli yöntemler farklı sonuçlar verecektir. Öğrenciler son derece yarışmacı bir yapıya sahip olabilirler. Grup çalışmalarından hoşlanmayabilirler. Böyle durumlarda o öğrencilerden maksimum yarar sağlanamaz.

İşbirlikli öğrenme ile ilgili bir eleştiri de yetenekli ve başarılı öğrencilerin öğretmen olarak kullanıldığının düşünülmesidir. Ancak bu durum uygun şekilde yapılandırılan işbirlikli öğrenme ortamı ile aşılmaktadır. Bunun yanında bir kişinin en iyi öğretirken öğreneceği görüşü de ön plana çıkmaktadır. Ayrıca yapılan araştırmalarda heterojen gruplarda gerçekleşen işbirlikli öğrenmede düşük yetenekli öğrencilerin başarısını, yüksek yeteneklilerin başarısını engellemeden yükselttiği ve öğretici durumunda olan öğrencilerin daha iyi öğrendikleri ortaya çıkmıştır (Açıkgöz, 2002).

Bir diğer eleştiri konusu da grup içinde üzerine düşen görevleri yerine getiremeyen öğrencilerin dışlanma korkusuna düşmesidir. Araştırmalarda işbirlikli öğrenmenin hem başarıyı arttırdığı hem de arkadaşlık ilişkilerini olumlu yönde etkilediği ifade edilmiştir (Baş, 2012; Doymuş, Şimşek \& Karaçöp, 2009; Doymuş, Şimşek \& Bayrakçeken, 2004).

Öğretimin etkili olmasında kullanılan yöntemlerin yanında duyuşsal özellikler de rol almaktadır. Duyuşsal özelliklerden birisi tutumdur. Tutum, gözlenebilen davranış değil, davranışa hazırlayıcı bir eğilimdir. Örneğin; futbol maçı yapmış birisinin susuzluktan kıvranırken su içmemesi, o kişinin bu durumda iken su içmeye karşı olumsuz bir tutuma sahip olduğunu gösterir. 
(sebep)

Tutum

Davranış

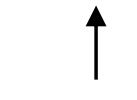

Gözlem

Şekil 1 Basit Tutum Davranış İlişkisi ( Atalay, 1998)

Duyuşsal özelliklerin yoklanmasında kullanılmak üzere bugüne kadar ortaya konmuş olan düzenler daha çok, uzun süreli gözlemlerden yararlanma ya da kişiye değişik durumlar sunarak onun bu durumlara tepkide bulunmasını sağlama şeklindedir (Özçelik,1988). Pratkanis ve arkadaşlarına (1988) göre tutum, bir bireyin bazı nesneler hakkında var olan bilgisini değerlendirmesidir (Bilgin \& Karaduman, 2005).

Günümüzde teknolojinin hızlı gelişimi sayesinde, iletişim ve bilgi alışverişi çok hızlı gerçekleşmektedir. Ülkelerin bu hızlı değişime ayak uydurarak sosyal, ekonomik ve kültürel anlamda gelişmesi, ancak donanımlı bir eğitim almış bireylerle olanaklıdır. $\mathrm{Bu}$ da ancak bireylerdeki potansiyeli ortaya çıkarıp, özgür ve yaratıcı düşünceyi desteklemekle gerçekleşecektir (Alkan, Deryakulu ve Şimşek, 1995).

Zacharias ve Barton'a (2004) tutumun kişisel inançlarla göre değişebileceğini ifade ederken; zamana karşı direnç gösterdiğini, öğrenilebilir olduğunu ve davranışlarla ilişkili olduğunu belirtmektedir. Duyuşsal özelliklerin ölçülmesinde, doğrudan gözlenemediğinden dolaylı ölçme yoluna gidilmektedir. Ayrıca, bu özellikler kişinin ne yapabildiği ile değil, kendi gönlüne bırakıldığında ne yaptığı ile ilgilidir. Bu yüzden ya uzun süreli gözlem yapma yoluna gidilmekte ya da öğrenci yapay durumlarla etkileştirilerek onun böyle durumlarda ne yapma eğiliminde olduğunun belirlenmesine çalışılmaktadır. İlgi envanteri, tutum ve özkavramı ölçekleri bu tür gruptaki ölçme araçlarındandır (Özçelik, 1988).

Duyuşsal özelliklerle ilgili davranışlar da bilişsel davranışlar gibi doğrudan gözleme elverişli değildir. Bu nedenle duyuşsal davranışların yukarıdaki iki yoldan biri ile yoklanması gerekir (Özçelik, 1988). Duyuşsal özellikleri belirleyen davranışların işaretçileri üzerinde uzun süre gözlem yapma koşulu, uygulamalarda genellikle zorluklara neden olur. Bu amaçla kişiye, yazılı olarak çok sayıda durumlar verilmekte ve ondan, bu durumlarda ne yapacağının belirtilmesi istenmektedir. Bundan farklı olarak da bir durum karşısında tutumunun ne olacağının belirtilmesi istenmektedir. Bu yol izlenirken kişinin, böyle bir durumla gerçekten karşılaşmış olması halinde de burada belirttiği davranışları göstereceği, başka bir deyişle sözü ile davranışının aynı olacağı kabul edilmektedir. 


\section{Araştırmanın Amacı}

Günümüzde öğrenciler, yarışmacı ortamda yetiştirilip hayata hazırlanmaktadır. Böyle ortamda gelişen bireylerin akademik olarak başarılı olmaları ve derslere olumlu tutum geliştirmeleri beklenmemektedir. Bu araştırmanın amacı; işbirlikli öğrenmenin çeşitli tekniklerinin, öğrencilerin fen ve teknoloji dersine yönelik tutumlarına ve akademik başarılarına etkisini incelemektir.

\section{Araştırmanın Problemi}

Fen bilimleri eğitimi öğrencilere verimli, kullanışlı ve etkili olarak verilmelidir. Bunun için öğretim esnasında bilginin özümsenmesi, anlamlandırılması ve yapılandırılması gerekmektedir. Bunun sağlanmasında öğrencilerin derse karşı olumlu tutum geliştirmesi etkilidir. Öğrencileri yarışmaya yönlendiren bir sistem, sosyal yönden gelişmelerine de engel olmaktadır. Arkadaşlarını rakip olarak gören bir öğrenci onlarla iletişimini koparmaktadırlar. İşbirliğine gitmeyen bu öğrenciler öğrenmelerini kendi çabalarıyla sağlamaya çalışmaktadırlar.

Bu çalışmada, "Genetik" ve "Canlılara Üreme ve Gelişme" ünitelerinin öğretiminde işbirlikli öğrenme yönteminin uygulandığı deney grubu ile geleneksel öğretim yönteminin uygulandığı kontrol grubu öğrencilerinin akademik başarıları ile Fen ve Teknoloji dersine yönelik tutumları arasında anlamlı bir fark olup olmadığının belirlenmesi araştırmanın problemini oluşturmaktadır. Bu probleme bağlı olarak şu sorulara cevap aranmıştır;

- İşbirlikli öğrenme yönteminin öğrencilerin akademik başarılarına etkisi var mıdır?

- İşbirlikli öğrenme yönteminin öğrencilerin Fen ve Teknoloji dersine yönelik tutumlarına etkisi var mıdır?

- İşbirlikli öğrenme yöntemi öğrencilerin kalıcı öğrenmelerine nasıl etki etmektedir?

\section{Yöntem}

\section{Araştırma Modeli}

$\mathrm{Bu}$ araştırma, ilköğretim öğrencilerinin fen dersine yönelik tutumlarını ve başarılarını geliştirmede işbirlikli öğrenmenin etkisini inceleyen deneysel bir çalışmadır.

$\mathrm{Bu}$ çalışmada, araştırmacıların deney ve kontrol gruplarındaki gelişim ve değişimleri izlemeleri amacıyla “Öntest-Sontest Kontrol Gruplu Deneme Modeli” kullanılmıştır (Karasar, 1999; Erdoğan, 2003; Gay, 1981). “Öntest-Sontest Kontrol Gruplu Deneme Modeli” deneysel işlemlerin bulunduğu ve araştırmacılar tarafından sıklıkla kullanılan bir modeldir. Bu modelin 
en önemli özelliği deney ve kontrol gruplarını barındırırken bu gruplar arasında rastlantısal seçime dayalı denklik kurulmaktadır (Cohen \& Manian, 1994).

$\mathrm{Bu}$ çalışma, ilköğretim 8. sınıf öğrencilerine “Genetik” ve "Canlılarda Üreme ve Gelişme" üniteleri boyunca işbirlikli öğrenme yöntemi uygulanarak öğrencilerin akademik başarılarına, fen ve teknoloji dersine karşı tutumlarına etkisini araştırmak üzere hazırlanmıştır.

Araştırmada kullanılan anket ve testlerin uygulanma deseni Tablo 1'de verilmiştir.

Tablo 1 Uygulamada Kullanılan Testlerin Uygulama Desenleri

\begin{tabular}{lccc}
\hline Gruplar & Ön testler & Uygulama yöntemleri & Son testler \\
\hline Kontrol grubu & Başarı Belirleme & Testleri (BBT), Fen \\
Tutum Ölçeği (FTÖ) & Geleneksel öğrenme yöntemi & BBT, FTÖ \\
Deney grubu & BBT, FTÖ & İşbirlikli öğrenme yöntemi & BBT, FTÖ \\
\hline
\end{tabular}

Tablo 1 incelendiğinde deney ve kontrol gruplarının oluşturulduğu ve deney grubunda işbirlikli öğrenme yöntemi, kontrol grubunda ise geleneksel öğretimin uygulandığ1 görülmektedir. Uygulamaya başlamadan önce hem deney hem de kontrol gruplarına BBT ve FTÖ ölçme araçları öntest olarak uygulanmıştır. Uygulama tamamlandıktan sonra da BBT ve FTÖ ölçme araçları sontest olarak verilmiştir.

Bu araştırma, Fen ve Teknoloji dersindeki "Genetik" ve "Canlılara Üreme ve Gelişme" ünitelerinde yürütülmüştür. Seçilen ders, ilköğretim sekizinci sınıfta, haftada üç ders saati işlenen bir derstir. Uygulamalar yaklaşık 4 ay sürmüştür.

Öğrencilerin uygulanan ölçme araçlarına ait öntest ve sontest puanları kullanılarak Fen ve Teknoloji dersine yönelik tutumlarında ve bu dersteki başarılarındaki gelişim ya da değişimin varlığı belirlenmeye çalışılmıştır.

\section{Çalışma Grubu}

Çalışma grubunu, Edirne İli Keşan İlçesindeki Anafartalar İlköğretim Okulunda 8. sınıfta öğrenim gören toplam 74 öğrenci oluşturmaktadır. Bu sınıflar, okul idaresi tarafından öğrenciler 5. sınıftan 6. sınıfa geçtikleri zaman (İlköğretimin II. Kademesine geçildiği yıl) kura yöntemi ile erkek ve kız sayıları tüm sınıflarda aynı olacak şekilde belirlenmektedir.

Okulun yapısı homojen bir grup özelliği göstermektedir. Bu özellik sınıfların daha önceki yıllarda sınıf geçme notlarında elde ettiği puanların birbirine çok yakın olmasıyla ortaya çıkmaktadır. 
Buna göre; araştırmaya katılan sınıflar ve bu sınıflardaki öğrenci sayılarının dağılımı Tablo 2'de verilmiştir.

Tablo 2 Öğrencilerin Cinsiyetlere Göre Sınıflara Dağılımı

\begin{tabular}{llll}
\hline & Kiz & Ëğrenciler & Toplam \\
\hline $8 / A$ & 15 & 22 & 37 \\
$8 / B$ & 15 & 22 & 37 \\
\hline
\end{tabular}

Yukarıdaki tablo verileri dikkate alındığında çalışma grubundaki deneklerin cinsiyet dağılımları değerlendirilmiş, gruplarda cinsiyet faktörüne göre bir yığılma olmadığı belirlenmiştir. Ayrıca sınıf mevcutları da eşitlik göstermektedir.

\section{Verilerin Toplanmasında Kullanılan Araçlar}

Araştırmada ölçme araçları olarak; öğrencilerin dersteki başarılarını ölçen "Başarı Belirleme Testleri” (BBT), öğrencilerin derse karşı tutumlarını ölçen "Fen Tutum Ölçeği”" (FTÖ) kullanılmıştır.

\section{Başarı Belirleme Testleri (BBT)}

Araştırmada kullanılan başarı belirleme testleri araştırmacılar tarafından hazırlanan ve geçerlilik ve güvenirlilik analizleri yapılmış 30 sorudan oluşan testlerdir. $\mathrm{Bu}$ testler hazırlanırken Milli Eğitim Bakanlığı İlköğretim 8. sınıf fen ve teknoloji dersinin ilgili ünitelerindeki kazanımlar göz önünde bulundurulmuştur.

“Genetik" ve "Canlılarda Üreme ve Gelişme” üniteleri için hazırlanan testlerde, önceki yıllarda yapılmış Ortaöğretim Kurumlarına Giriş Sınavı soruları ve araştırmacıların hazırladığı sorular kullanılmıştır. Öğretim programında bulunan kazanımlar göz önünde bulundurularak hazırlanan testler başka bir okulun Fen ve Teknoloji öğretmeni tarafindan incelenerek 40 soruya indirilmiştir. Tekrar test yöntemine göre hazırlanan testlerin pilot uygulamaları yapılmış ve çalışmada kullanılmıştır. Geçerlilik ve güvenirlik hesaplamaları yapılarak testler 30 soruya indirilmiştir. "Genetik" ünitesinin başarı testinin güvenirlik katsayısı, 0,89 hesaplanmıştır. "Canlılarda Üreme ve Gelişme” ünitesinin başarı testinin güvenirlik katsayısı ise 0,86 bulunmuştur.

Araştırma verilerinin normal dağılım göstermesi nedeniyle parametrik testler uygulanmıştır. Grupların öntest puan ortalamaları, standart sapmaları ve gruplar arasında 
anlamlı bir farkın olup olmadığı " $\mathrm{t}$ " testiyle incelenmiş, gözlenen " $\mathrm{t}$ " değerlerinin .05 manidarlık düzeyinde anlamlı olup olmadığı incelenmiştir.

Üniteler uygulandıktan sonra sontestler ve 3 hafta sonra hatırlama testleri yapılmış, gruplar arasında anlamlı bir farkın olup olmadığı "t" testi ile incelenmiştir. İşbirlikli öğrenmenin uygulandığ 1 deney grubu ile geleneksel yöntemin uygulandığ kontrol grubunun sontest ortalamaları ve standart sapmaları hesaplanmıştır. Aynı zamanda grupların uygulama öncesi ile uygulama sonrası farkının anlamlı olup olmadığına yine "t" testi ile bakılmıştır. Değerlerin .05 manidarlık düzeyinde anlamlı olup olmadığı incelenmiştir.

\section{Fen ve Teknoloji Dersi Tutum Ölçeği (FTÖ)}

Fen ve Teknoloji Dersi Tutum Ölçeği (FTÖ); 10 adet olumlu, 5 adet olumsuz cümle yapısında toplam 15 soru içeren 5'li likert tipi fen tutum ölçeği, Geban, Ertepınar, Yılmaz, Altın ve Şahbaz (1994) tarafından geliştirilmiş ve Cronbach alfa güvenirlik katsayısı 0,83 olarak bulunmuştur. Fen ve Teknoloji Dersi Tutum Ölçeği, öğrencilerin fen ve teknoloji dersine karşı tutumlarını belirlemek amacıyla kullanılmıştır.

Fen ve Teknoloji dersine olan tutum ile ilgili çeşitli anketler (Hasan, 1985; Gogolin \& Swartz, 1992; Gabel, 1994) hazırlanmış olup, bu çalışmada Geban ve arkadaşlarının (1994) uyguladığı anket kullanılmıştır. Öğrencilerin derse yönelik tutum düzeylerindeki değişimin belirlenmesi için deney grubu ile kontrol grubunun tutum puanlarının ortalamaları, standart sapmaları ve " $\mathrm{t}$ ” testi sonuçları .05 manidarlık düzeyinde incelenip yorumlanmıştır.

\section{Dersin İşlenişi}

Ünitenin hedef ve kazanımlarını kazandıracak şekilde günlük ders planları işbirlikli öğrenme etkinliklerine göre hazırlamıştır. Derslerin işlenişi sırasında işbirlikli öğrenme gruplarında çalışmalar yapılmıştır. Soru-cevap, tartışma, deney, gözlem, çizim, anlatım, beyin firtınası gibi uygulamalar bu gruplar bünyesinde sürdürülmüştür. Bunun yanında örneğin “DNA Denilen Hücredeki Özel Molekül Ne İşler Yapar?” konusu Jigsaw, “Akraba Evliliği Neden Sakıncalı?" Akademik Çelişki, "Kalıtım İnsanda Cinsiyeti de Belirler" konusu ise Birlikte Soralım Birlikte Öğrenelim teknikleri ile işlenmiştir.

Çalışma Milli Eğitim Bakanlığı tarafından yayınlanan öğretim programı esas alınarak, programdan belirtilen kazanımlara göre uygulanmıştır. Araştırma esnasında uygulanan tüm ders planları araştırmacılar tarafından hazırlanmıştır. Hazırlanan bu planlar her iki grupta da araştırmacılardan birisi tarafından uygulanmıştır. 


\section{Verilerin Çözümlenmesi}

Yapılan araştırmada uygulama öncesi ile uygulama sonrası öğrencilerin başarı ve tutum puanları nicel olarak ölçülmüştür. Araştırmadan edilen bulgularla deney ve kontrol grupları arasında anlamlı farkın olup olmadığg SPSS Paket Programı kullanılarak incelenmiştir. Her iki grubun ön test ve son test karşılaştırmalarında bağımsız grup ' $\mathrm{t}$ ' testi kullanılmıştır. Anlamlılık düzeyleri .05 olarak kabul edilmiştir.

\section{Bulgular ve Yorumlar}

\section{Fen ve Teknoloji Dersine Karşı Tutum Puanlarına İlişkin Bulgular}

Araştırmada belirlenen modele göre; uygulamadan önce ve her iki ünitedeki uygulamanın sonunda öğrencilerin derse karşı tutumlarını belirlemek için uygulanan FTÖ’nün ön ve son testlerinden elde edilen analiz sonuçları Tablo 3 'te verilmiştir.

Tablo 3 Deney ve Kontrol Gruplarına Uygulanan Tutum Anketinden Elde Edilen Verilerin Bağımsız t Testi Sonuçları

\begin{tabular}{|c|c|c|c|c|c|c|c|}
\hline Testler & Gruplar & $\mathbf{N}$ & $\mathbf{X}$ & $\mathbf{S}$ & sd & $\mathbf{t}$ & $\mathbf{p}$ \\
\hline Uygulama & Deney & 37 & 29,16 & 9,456 & \multirow[b]{2}{*}{72} & \multirow[b]{2}{*}{,499 } & \multirow[b]{2}{*}{,620 } \\
\hline Öncesi & Kontrol & 37 & 28,16 & 7,708 & & & \\
\hline Genetik & Deney & 37 & 26,62 & 9,236 & \multirow{3}{*}{72} & \multirow{3}{*}{, 153} & \multirow{3}{*}{,879 } \\
\hline Ünitesi & & & & & & & \\
\hline Sonrast & Kontrol & 37 & 26,32 & 7,368 & & & \\
\hline $\begin{array}{l}\text { Canllarda } \\
\text { Üreme ve }\end{array}$ & Deney & 37 & 28,30 & 9,140 & \multirow{3}{*}{72} & \multirow{3}{*}{, 100} & \multirow{3}{*}{,921 } \\
\hline $\begin{array}{l}\text { Gelişme } \\
\text { Ünitesi }\end{array}$ & Kontrol & 37 & 28,49 & 6,975 & & & \\
\hline Sonrast & & & & & & & \\
\hline
\end{tabular}

Tablo 3'e göre uygulama öncesi öğrencilerin FTÖ ön testlerindeki deney ve kontrol gruplarının ortalama puanları arasında önemli bir farkın olmadığı $(\mathrm{p}>0,05)$ görülmektedir. İlk ünite olan Genetik ünitesi ile ikinci ünite olan Canlılarda Üreme ve Gelişme ünitesi tamamlandıktan sonra uygulanan FTÖ ortalama puanları incelendiğinde deney ve kontrol gruplarının ortalama puanları arasında istatistiksel olarak önemli bir farkın olmadığ $\left(\mathrm{p}_{1}>0,05\right.$ ve $\left.\mathrm{p}_{2}>0,05\right)$ görülmektedir. 


\section{Başarı Puanlarına İlişkin Bulgular}

Birçok uygulamada olduğu gibi bu çalışmada da grupların başarı düzeyleri de karşılaştırılmıştır. Grupların farklılık gösterip göstermediği incelenmiştir. Gruplar arasında başarı puanları açısından fark olup olmadığı Tablo 4'te verilmiştir.

Tablo 4 Deney ve Kontrol Gruplarına Uygulanan Genetik Ünitesi Başarı Testinden Elde Edilen Verilerin t Testi Sonuçları

\begin{tabular}{llllllll}
\hline Testler & Gruplar & N & $\mathbf{X}$ & S & sd & t & p \\
\hline Ontest & Kontrol & 37 & 10,35 & 2,552 & & & \\
& Deney & 37 & 10,19 & 1,221 & 72 &, 349 &, 728 \\
\hline \multirow{2}{*}{ Sontest } & Kontrol & 37 & 12,65 & 3,182 & 72 & 5,273 &, 000 \\
& Deney & 37 & 16,51 & 3,124 & & & \\
\hline $\begin{array}{l}\text { Hatrlama } \\
\text { Testi }\end{array}$ & Kontrol & 37 & 12,16 & 3,014 & & & \\
\hline
\end{tabular}

Genetik Ünitesi uygulama öncesi grupların ortalama başarı puanları arasında istatistiksel olarak anlamlı bir farkın olmadığı görülmektedir ( $>>0,05)$. Gruplar uygulama öncesi eşit düzeydedir. Genetik Ünitesi sonrasında uygulanan başarı testi sonuçlarına bakıldığında işbirlikli öğrenme yönteminin uygulandığ 1 deney grubu ile geleneksel yöntemin uygulandığı kontrol grubu ortalama puanları $\left(\mathrm{X}_{\mathrm{deney}}=16,51 ; \mathrm{X}_{\text {kontrol}}=12,65\right)$ arasında istatistiksel olarak anlamlı bir farkın olduğu $(\mathrm{p}<0,05)$ görülmektedir. Bu fark deney grubu lehinedir.

Genetik ünitesi tamamlandıktan 30 gün sonra her iki gruba da sontest olarak uygulanan başarı testleri "Hatırlama Testi “olarak tekrar uygulanmıştır. Benzer şekilde bu ünite sonrası uygulanan hatırlama testi sonuçlarına bakıldığında işbirlikli öğrenme yönteminin uygulandığı deney grubu ile geleneksel yöntemin uygulandığ 1 kontrol grubu ortalama puanları ( $\mathrm{X}_{\text {deney}}=$ 15,70; $X$ kontrol= 12,16) arasında istatistiksel olarak anlamlı bir farkın olduğu $(\mathrm{p}<0,05)$ görülmektedir. Bu fark deney grubu lehinedir. Hatırlama testlerinden elde edilen verilerin analiz sonuçlarına göre işbirlikli öğrenme yöntemi ile işlenen dersin daha kalıcı olduğu söylenebilir.

Tablo 5 Deney ve Kontrol Gruplarına Uygulanan Canlılarda Üreme ve Gelişme Ünitesi Başarı Testinden Elde Edilen Verilerin t Testi Sonuçları 


\begin{tabular}{|c|c|c|c|c|c|c|c|}
\hline Testler & Gruplar & $\mathbf{N}$ & $\mathbf{X}$ & $\mathbf{S}$ & sd & $\mathbf{t}$ & $\mathbf{p}$ \\
\hline \multirow{3}{*}{ Öntest } & Kontrol & 37 & 10,35 & 2,552 & \multirow{3}{*}{72} & \multirow{3}{*}{,921 } & \multirow{3}{*}{,360 } \\
\hline & & & & & & & \\
\hline & Deney & 37 & 10,84 & 1,951 & & & \\
\hline \multirow{3}{*}{ Sontest } & Kontrol & 37 & 13,35 & 2,781 & \multirow{3}{*}{72} & \multirow{3}{*}{5,790} & \multirow{3}{*}{,000 } \\
\hline & & & & & & & \\
\hline & Deney & 37 & 17,59 & 3,484 & & & \\
\hline \multirow{2}{*}{$\begin{array}{l}\text { Hattrlama } \\
\text { Testi }\end{array}$} & Kontrol & 37 & 12,89 & 3,406 & \multirow[b]{2}{*}{72} & \multirow[b]{2}{*}{6,242} & \multirow[b]{2}{*}{,000 } \\
\hline & Denev & 37 & 17.41 & 2783 & & & \\
\hline
\end{tabular}

Canlılarda Üreme ve Gelişme Ünitesi uygulama öncesi grupların ortalama başarı puanları arasında istatistiksel olarak anlamlı bir farkın olmadığı görülmektedir ( $>>0,05)$. Gruplar uygulama öncesi eşit düzeydedir. Canlılarda Üreme ve Gelişme Ünitesi sonrasında uygulanan başarı testi sonuçlarına bakıldığında işbirlikli öğrenme yönteminin uygulandığı deney grubu ile geleneksel yöntemin uygulandığı kontrol grubu ortalama puanları ( $\mathrm{X}_{\text {deney }}=$ 17,59; $X$ kontrol= 13,35) arasında istatistiksel olarak anlamlı bir farkın olduğu $(p<0,05)$ görülmektedir. Bu fark deney grubu lehinedir.

Canlılarda Üreme ve Gelişme Ünitesi tamamlandıktan 30 gün sonra her iki gruba da sontest olarak uygulanan başarı testleri "Hatırlama Testi "olarak tekrar uygulanmıştır. Benzer şekilde bu ünite sonrası uygulanan hatırlama testi sonuçlarına bakıldığında işbirlikli öğrenme yönteminin uygulandığı deney grubu ile geleneksel yöntemin uygulandığı kontrol grubu ortalama puanları $\left(\mathrm{X}_{\text {deney }}=17,41 ; \mathrm{X}\right.$ kontrol$\left.=12,89\right)$ arasında istatistiksel olarak anlamlı bir farkın olduğu $(p<0,05)$ görülmektedir. Bu fark deney grubu lehinedir. Hatırlama testlerinden elde edilen verilerin analiz sonuçlarına göre işbirlikli öğrenme yöntemi ile işlenen dersin daha kalıcı olduğu söylenebilir.

\section{Sonuç ve Tartışma}

İşbirlikli öğrenmenin tutum ve başarıya etkisini incelediğimiz bu araştırmada uygulama öncesi ve uygulamalar sonrası öğrencilerin tutumlarında deney ve kontrol gruplarında anlamlı bir fark bulunmamıştır. Deney grubunun akademik başarısı ise kontrol grubuna göre anlamlı düzeyde artış göstermiştir. Altıparmak ve Nakipoğlu (2002), yaptığı çalışmada işbirlikli öğrenme yönteminin öğrencilerin tutum ve akademik başarılarına etkisini incelemiştir. Öğrencilerin akademik başarılarının deney grubu lehine artığını, tutumların ise gruplar 
arasında anlamlı düzeyde farklılık göstermediğini belirlemişlerdir. Bu sonuçlar çalışmayla uyumludur.

Baykul (1990) derse ilişkin tutumlarla başarı arasındaki ilişkiyi inceleyen bir araştırma gerçekleştirmiştir. Baykul, yaptığı çalışmayla ilkokul beşinci sınıf düzeyinde lise ve dengi okulların son sınıf düzeylerine kadar matematik ve fen derslerine yönelik öğrencilerin tutumlarında görülen farklılıklar ve öğrencilerin girmiş olduğu sınavdaki başarı ile ilişkisi olduğu düşünülen bazı faktörleri araştırmıştır. Matematiğe karşı tutum ile ÖSS matematik alt testi puanları arasında lise ve dengi okulların 3. sınıfları için pozitif yönde bir ilişki vardır. İlkokul beşinci sınıf ve ortaokul sınıfları için böyle bir ilişki olduğunu gösteren kanıt yoktur. Matematiğe karşı tutum ile ÖSS matematik alt testi puanları arasındaki en yüksek korelasyon lise fen kolu ve imam hatip lisesi 3. sınıfta gözlenmiştir.

Sünbül (1998) yaptığı araştırmada, Orta II Milli Tarih dersinde işbirlikli öğretim yönteminin kullanılması sırasında grupla değerlendirme, bireysel değerlendirme ve değerlendirme yapmamanın öğrenci erişi ve tutumları üzerindeki etkisini incelemiştir. Araştırma bulgularına göre, 1. Orta II Milli Tarih dersinde işbirliğine dayalı öğretim yönteminin kullanılması sırasında grupla değerlendirme, bireysel değerlendirme ve hiçbir değerlendirme yapmama öğrenci erişileri arasında anlamlı bir fark vardır.

Çalışmadan elde edilen veriler incelendiğinde gruplar içinde tutum puanları açısında deney ve kontrol gruplarında herhangi bir anlamlı farklılık görülmemiştir.

İşbirlikli öğrenme bir çok araştırmada görüldüğü gibi öğrencilerin başarılarını artırmaktadır. Yapılan çalışmada da öğrencilerin başarılarını artırdığı görülmektedir. Deney grubundaki başarı artışı kontrol grubuna göre daha yüksektir. Ancak bu farklılık anlamlı düzeyde değildir.

Nakiboğlu ve Benlikaya ise (2001) "Maddenin Oluşumu” ünitesinde; tam öğrenmeye dayalı işbirlikli öğrenme yönteminin, öğrenme-öğretme sürecine etkisini incelemişlerdir. Ayrıca, deney grubunda bulunan öğrenciler için duyuşsal ürünlerin ve öğrenme hızının incelenmesinde, öğrencilerden aldıkları yazılı görüşler ve öğretmenin ders esnasında yapmış olduğu gözlemler kullanılmıştır. Uygulamanın tamamlanması ile 3 bölümden oluşan bir test kullanılmış ve deney grubu öğrencilerinin bilişsel beceriler bakımından daha başarılı bulunmuştur.

Baykara'nın (2000) yaptığı araştırmada; İşbirliğine dayalı öğrenme tekniklerinden olan "Karş1lıklı Sorgulama" ve "Birleştirme" tekniklerinin öğrenci hatırlama düzeyine ve erişisine etkisi karşılaştırılmalı olarak incelenmiştir. Bu etkinin farklı değişkene bağlı olarak değişip 
değişmediği belirlenmek amacıyla öğrencilerin denetim odaklarına bağlı olup olmadıklarını göz önünde bulundurmuştur. Araştırmadan elde edilen bulgulara göre "Karş1lıklı sorgulama" ve "birleştirme" teknikleri öğrencilerin ve hatırlama düzeylerini olumlu yönde etkilemektedir. Birleştirme tekniği Karşılıklı Sorgulama ve Birleştirme tekniklerinin uygulandığı gruplardaki tüm iç ve diş denetimli öğrencilerin erişileri, hatırlama düzeyleri ve izleme testlerinden elde ettikleri puanları arasında anlamlı bir farklılık bulunamamıştır.

Altıparmak ve Nakipoğlu'nun (2002), yaptığı çalışmada da işbirlikli öğrenme yöntemini kullanarak öğrencilerin tutum ve başarılarını ölçmüş, başarılarının artarken, tutumların değişmediğini bulmuştur.

Bir diğer araştırma da, Açıkgöz’ün (1990) yaptı̆̆ı işbirliğine dayalı öğrenmenin tekniklerinden olan Birlikte Soralım Birlikte Öğrenelim Tekniği ile düz anlatım, soru-yanıt ve tartışma tekniklerinin kullanıldığı geleneksel öğretimin üniversite öğrencilerinin öğrenme ve hatırda tutma düzeyleri ile duyuşsal özellikleri üzerindeki etkilerini incelediği araştırmadır. Birlikte Soralım birlikte Öğrenelim grubu ve geleneksel öğretim grupların ünite sonu akademik başarı düzeyi açısından önemli farklılığın olup olmadığının belirlenmesi için önce Birlikte Soralım Birlikte Öğrenelim ve geleneksel öğretim gruplarının aldıkları puanlar incelenmiştir. Elde edilen sonuçlara göre grupların ortalamaları arasındaki farkın önemli olduğu belirlenmiştir. Diğer bir ifade ile Birlikte Soralım Birlikte Öğrenelim grubu son testte geleneksel öğretim grubundan daha başarılı olmuştur.

Çalışmanın diğer bir denencesinin sınanması için, geleneksel öğretimin ve işbirliğine dayalı öğrenmenin öğrencilerin hatırda tutma düzeyleri üzerindeki etkileri arasında anlamlı bir farklılığın belirlenmesi amacıyla aldıkları puanlar hesaplanmıştır. $\mathrm{Bu}$ puanlar incelendiğinde geleneksel öğretimin ve işbirliğine dayalı öğrenmenin uygulandığı grupların Hatırda Tutma Testi Ortalamaları arasındaki farkın anlamlı olduğu, yani işbirliğine dayalı öğrenme grubunun son testteki başarı düzeyinin geleneksel öğrenme grubuna göre daha yüksek olduğu belirlenmiştir.

Yapılan diğer bir araştırmada (Genç \& Şahin, 2005), işbirlikli öğrenme gruplarıyla üretilen kavram haritalarının öğrencilerin öğrenmelerine etkisi araştırılmıştır. Araştırmada kontrol grubunda sadece işbirlikli öğrenme yöntemi uygulanırken, deney grubunda ise işbirlikli öğrenme gruplarının kavram haritaları yapmaları sağlanmıştır. Her iki grubun öğrenme düzeyleri açısından farklılıkları araştırılmıştır. Çalışmanın verileri araştırmacılar tarafından hazırlanan Başarı Belirleme Testi ile öğrencilerin işbirlikli öğrenme gruplarında yaptıkları kavram haritalarından elde edilmiştir. Sonuçlara göre işbirlikli öğrenme grubuyla 
yapılan kavram haritalarının öğrencilerin öğrenmelerine anlamlı düzeyde etkisi olduğu belirlenmiştir.

Yapılan başka bir araştırmada (Doymuş, Şimşek \& Bayrakçeken, 2004) işbirlikli öğrenme yönteminin kullanıldığı deney grubu ile geleneksel öğrenme yönteminin kullanıldığ kontrol grubunun Fen Bilgisi Dersindeki akademik başarısı, derse yönelik tutumları incelenmiştir. Sekiz hafta süren bir uygulama sonunda son-test olarak uygulanan FBT verilerine göre işbirlikli öğrenme grubunun, geleneksel öğrenmel grubundan daha başarılı olduğu sonucuna varılmıştır. Bu sonuç çalışmadaki sonuçla uyumludur.

Bir diğer çalışmada Bilgin ve Karaduman (2005), yaparak-yaşayarak fen etkinliklerinin işbirlikli öğrenme yaklaşımı ve öğretmen merkezli öğretim yaklaşımı ile verilmesinin, ilköğretim sekizinci sınıf öğrencilerinin fen dersine karşı tutumlarına etkisi incelenmiştir. Çalışma sonucunda, öğrencilerin ön-FTÖ puanları ortak değişken olarak kullanıldığında, işbirlikli öğrenme grubu ve öğretmen merkezli öğrenme grubunun son-FTÖ puanların ortalamaları arasında istatistiksel olarak, deney grubu lehine anlamlı bir fark olduğu tespit edilmiştir.

Öğrenciler eğitim hayatına başladıkları ilk zamanlarda itibaren genellikle geleneksel öğrenme yöntemiyle eğitim görmüşler ve bireysel farklılıklarını gösterme imkanı bulamamışlardır. Bireyin sahip olduğu alışkanlıklarını terk etmesindeki zorluk öğrencilerin farklı öğretim yöntemine alışmaları sürecinde de ortaya çıkmaktadır. Bu sürece uyum için uzun zamana ihtiyaç vardır.

Fen ve Teknoloji dersine karşı öğrencilerin tutum değerleri uygulama öncesi eşit düzeyde iken uygulamalar sonrası da farklılık görülmemiştir. Tutum uzun sürede oluşan kişisel bir değerlendirme olduğu için tutumdaki değişimi oluşturabilmek için uzun süreli çalışma yapılması gerekmektedir. Bu yargıya özellikle öğrencilerin ders hakkında söyledikleri sözlü ifadelerden ulaşılmıştır. Araştırma öncesi iki grupta da Fen ve Teknoloji dersinin sevimsiz olduğunu ve sınav için zorla çalıştıklarını söyleyenler çoğunluktayken, uygulamalar sonrası deney grubundaki birçok öğrenci bu dersin çok zevkli ve eğlenceli bir hal aldığını belirtmişlerdir. Ancak deney grubundaki bu değişim anlamlı düzeyde olmamıştır.

Öğrencilerin başarı düzeylerinde de farklı sonuçlar elde edilmiştir. Uygulama öncesi eşit düzeyde olan iki grup uygulamalar sonrası farklılıklar göstermişlerdir. Kontrol grubu ünite tamamlandıktan sonra başarı düzeylerini artırmış ancak hatırlama testlerinde düşüş yaşamışlardır. Deney grubu ise; üniteler tamamlandıktan sonra başarı düzeylerini kontrol 
grubuna göre anlamlı olacak derecede artırmış ve hatırlama testlerinde de bu anlamlı farkı koruyarak başarılı olmuşlardır.

\section{Öneriler}

Derslerde işbirlikli öğrenme yönteminin kullanılması başarıyı artırdığına göre bu yöntemin diğer derslerde de kullanılması önerilebilir. Bu araştırma ilköğretim sekizinci sınıf öğrencileri ile yapılmıştır. $\mathrm{Bu}$ sürece kadar öğrencilerin kişisel yapıları şekillenmeye başlamıştır. Bu tür çalışmaların ilköğretimin ilk sınıflarından itibaren yapılması öğrencilerin sosyal gelişimlerine de destek olacağı düşünülmektedir.

$\mathrm{Bu}$ tür uygulamalardan sonra elde edilen verilerin incelenip uzman araştırmacılar tarafından öğrencilere rehberlik yapılmalıdır. Eğitim öğretim sonunda yapılan sınavlar öğrenciler üzerinde olumsuz etki oluşturduğu için uygulamalarda dikkat edilmesi gereklidir. Öğrencilerin gelişimleri düzeyleri ve akademik başarıları süreç içinde değerlendirilmeli ve bu verilere göre uygulamalar güncellenmelidir.

$\mathrm{Bu}$ çalışmaya benzer çalışmalar fen bilgisi dersi dışındaki derslerde yapılarak, sonuçları karşılaştırılmalı ve bu sonuçlara göre yeni öneriler ve uygulamalar sunulmalıdır. Bu tür çalışmaların diğer derslerde daha etkili olup olmadığı incelenmelidir. Dersin yapısı ve ders içeriklerinden kaynaklanan farklılıklar göz önünde bulundurularak uygulama planları hazırlanmalıdır.

Eğitim programlarının uygulanmasında öğrencinin ilgi ve tutumunu artıracak farklı yöntemler uygulanmalıdır. Başarılı olan bir yöntemin uzun süre kullanılması uygulamanın etkisini azaltabilir. Öğrenciyi aktif kılacak farklı uygulamaların öğrenci başarısını destek olacağ1 düşünülmektedir.

Tutumlar süreç boyunca çeşitli etkiler sonucu oluşmakta ve yine uzun süren etkiler sonrası değişsebilmektedir. Başarısı belirlenmiş bu tür uygulamalar daha uygun bir program dahlinde uygulanmalı ve belirlenen programın geri dönütleri sürekli alınmalıdır. Yapılacak değişiklikler ise en sınıflardan başlayarak kademeli olarak üst sınıflarda uygulanmalıdır. Eğitim hayatları boyunca benzer bir programda eğitim alan öğrencilerin, farklı yöntemleri kapsayan yeni bir programa geçişleri zor olacaktır. 


\section{Kaynakça}

Açıkgöz, K. (1990). İşbirliğine Dayalı Öğrenme Ve Geleneksel Öğretimin Üniversite Öğrencilerinin Akademik Başarısı, Hatırda Tutma Düzeyleri Ve Duyuşsal Özellikleri Üzerindeki Etkileri, A.Ü. Eğitim Bilimleri Fakültesi: I. Ulusal Eğitim Bilimleri Kongresi (25-28 Eylül 1990). Ankara: MEB yay. 187-201.

Açıkgöz, K.Ü. (2002). Aktif Öğrenme. Eğitim Dünyası Yayınları, İzmir.

Alkan, C., Deryakulu D., \& Şimşek N., (1995). Öğretim Teknolojilerine Giriş “Disiplin Süreç Ürün”. Ankara: Önder Matbaacılık.

Altıparmak, M., \& Nakipoğlu, M. (2002). Lise Biyoloji Laboratuarlarında "İşbirlikli Öğrenme” Yönteminin Tutum ve Başarıya Etkisi. V. Ulusal Fen Bilimleri ve Matematik Eğitimi Kongresi Bildiriler Kitab1.

Atalay, E. (1998). Temel Ĕ̆itim II. Kademe Öğrencilerinin Müziğe İlişkin Tutumlarının Ölçülmesi, Yayınlanmamış Yüksek Lisans Tezi, Marmara Üniversitesi Fen Bilimleri Enstitüsü, İstanbul.

Baş, G. (2012). The Effects of Cooperative Learning Method On Students' Achievement and Attitudes Towards English Lesson. Journal of Theory and Practice in Education, 8(1), 72-93.

Baykara, K. (2000). İşbirliğine Dayalı Öğrenme Teknikleri ve Denetim Odakları Üzerine Bir Çalışma, Hacettepe Üniversitesi Ĕ̆itim Fakültesi Dergisi, (18), Ankara.

Baykul, Y. (1990). Illkokul Beşinci Sinıftan Lise ve Dengi Okulların Son Sinıflarına kadar Matematik Ve Fen Derslerine Karşı Tutumda Görülen Değişmeler ve Öğrenci Seçme Sınavındaki Başarı Ile İlişkili Olduğu Düşünülen Bazı Faktörler, ÖSYM Yayınları, Ankara.

Bilgin, İ. \& Karaduman, A. (2005). İşbirlikli Öğrenmenin 8. Sınıf Öğrencilerinin Fen Dersine Karş1 Tutumlarına Etkisinin İncelenmesi, İlköğretim-Online, 4(2), 32-45, 2005 [Online]:http://ilkogretim-online.org.tr adresinden 22.02.2006 tarihinde indirilmiştir.

Cohen, L. \& Manian, L. (1994). Research Methods in Education. London: Routledge.

Conwell, C. R. (1988). Students' perceptions when working in cooperative problem solving groups. Paper presented at the North Carolina Science Teachers Association Convention. ERIC Document Reproduction Service. ED 313455. 
Doymuş, K., Şimşek, \& Ü., Bayrakçeken, S. (2004). “İşbirlikçi Öğrenme Yönteminin Fen Bilgisi Dersinde Akademik Başarı ve Tutuma Etkisi”, Türk Fen Eğitimi Dergisi, Yıl 1 Sayı 2; 103-115.

Doymuş, K., Şimşek, Ü. \& Karaçöp, A. (2009). The Effects of Computer Animations And Cooperative Learning Methods in Micro, Macro And Symbolic Level Learning of States of Matter. Eurasian Journal of Educational Research, Issue 36, 109-128.

Erdoğan, İ. (2003). Pozitivist Metodoloji, Bilimsel Araştırma Tasarımı, İstatistiksel Yöntemler, Analiz ve Yorum. Ankara: Erk Yayınevi.

Gabel, D. L. (1994). Handbook of Research on Science Teaching and Learning. New York: Mamillan.

Gay, L. R. (1981). Educational Research: Competencies for Analysis and Application. Columbus, Ohio: Merrill Publishing Co.

Geban, Ö., Ertepınar, H., Yılmaz, G., Altın, A., \& Şahbaz, F. (1994). Bilgisayar destekli eğitimin öğrencilerin fen başarılarına ve fen bilgisi ilgilerine etkisi. Dokuz Eylül Üniversitesi, I. Ulusal Fen Bilimleri Eğitimi Sempozyumu Bildiri Özetleri Kitabı, İzmir.

Genç, M., \& Şahin, F. (2004). The Effects Of Cooperative Learning With Concept Map To Learn In Science Education, $2^{\text {nd }}$ International Balkan Education Congress, Searching Excellence in Education, October, Edirne.

Gogolin, L. \& F. Swartz. (1992). A Quantitative and Qualitative Inquiry into the Attitudes Toward Science of Nonscience College Students. Journal of Research in Science Teaching, 29(5), 487-504.

Hasan, O. E. (1985). An Investigation into Factors Affecting Attitudes toward Science of Secondary School Students in Jordan. Science Education, 69, 3-18.

Jones, R. M. ve Steinbrink, J. E. (1991). Home teams: Cooperative learning in elementary science. School Science and Mathematics, 91(4), 139-143.

Kaptan, F. ve Korkmaz H. (2001). İşbirliğine dayalı fen öğretiminin öğretmen adaylarının özyeterlik düzeylerine etkisi, IV. Fen Bilimleri Eğitimi Kongresi. Ankara: Milli Eğitim Basımevi.

Karasar, N. (1999). Bilimsel Araştırma Yöntemi. Nobel Yayın Dağıtım. Ankara

Korkmaz, H. (2002). Fen eğitiminde proje tabanlı öğrenmenin yaratıcı düşünme, problem çözme ve akademik risk alma düzeylerine etkisi, Yayımlanmamış Doktora Tezi, Hacettepe Üniversitesi, Sosyal Bilimler Enstitüsü, Ankara. 
Kurt, I. (2001). Fen Eğitiminde İşbirlikli Öğrenme Yönteminin Öğrencilerin Başarısına, Kavram Öğrenmesine ve Hatırlamasına Etkisi, Marmara Üniversitesi, Eğitim Bilimleri Enstitüsü, İlköğretim Bölümü Sınıf Öğretmenliği Anabilim Dalı, Yayınlanmamış Yüksek Lisans Tezi, İstanbul, 2001.

Lev, M. M. (1997). The Connection between Cooperative Learning and Authentic Assessment, Sabes, Vol:10, http://www.sabes.org/resources/adventures/vol10/10mangan.html adresinden 10.10.2004 tarihinde indirilmiştir.

Millis, B. J. (1996). The University of Tennessee at Chattanooga Instructional Excellence Retreat, May.

Nakiboğlu, C., \& Benlikaya R. (2001). "Maddenin Oluşumu” Ünitesinin Tam Öğrenmeye Dayalı İşbirlikli Öğrenme Yöntemi İle İşlenmesinin Öğretme Öğrenme Sürecine Katkıları, Çukurova Üniversitesi Eğitim Fakültesi Dergisi S:21 Adana.

Okebukola, P. A. (1986). Cooperative learning and students' attitudes to laboratory work. School Science and Mathematics, 86(7), 582-590.

Özçelik, D. A. (1988). Ĕgitim Bilimleri Ölçme ve Değerlendirme, Açıöğretim Fakültesi Yayınları, Eskişehir, 53-57.

Sünbül, A. M. (1998). Öğrenme Stratejilerinin Öğrenci Erişi ve Tutumlarına Etkisi Yayınlanmamış Doktora Tezi. Ankara: Hacettepe Üniversitesi, Sosyal Bilimler Enstitüsü.

Zacharias, Z. \& Barton, A. C. (2004). Urban middle-school students' attitudes toward a defined science. Science Education, (88), 197-222. 